\title{
Mini and Microsatellite DNA Analyses of the Irradiated Sperm Transformed Chickens
}

\author{
Naoyuki Yamamoto ${ }^{1)}$, Katsutoshi $\mathrm{K}_{\mathrm{INO}^{2)}}$, Hideki $\mathrm{K}_{\mathrm{ATOH}}{ }^{1)}$, \\ Takahiro Yamagata ${ }^{3)}$ and Takeshi Tomita ${ }^{3)}$ \\ 1) Department of Genetics, Central Institute for Experimental Animals, \\ 1430 Nogawa, Miyamae, Kawasaki 216 \\ 2) Poultry Research Institute, Aichi-ken Agricultural \\ Research Center, Nagakute, Aichi 480-11 \\ 3) Laboratory of Animal Genetics, School of Agricultural Sciences, \\ Nagoya University, Furocho, Chikusa, Nagoya 464-01
}

We analysed our irradiated sperm transformed (IST) chicken DNA for minisatellite loci by DNA fingerprinting and the microsatellite DNA by PCR method.

The direct coordination between brownish egg shell color and DNA fingerprint bands was not recognized under this study condition. The genetic similarities of WL- $r$ 5 (IST line), WL-G (recipient line) and RIR-Y8 (donor line) by using band sharing (BS) values were calculated from the number of DNA fingerprint bands derived from mixed DNA. The value of $B S$ between WL- $r 5$ and WL-G was 0.61 in HaeIII digestion bands and 0.48 in HinfI digestion bands. The $B S$ value between WL- $r 5$ and RIR-Y 8 was 0.26 in Hae III digestion bands and 0.15 in HinfI digestion bands. Comparison of the DNA fingerprint of mixed DNA for each strain was made and the common band in both WL$r 5$ and RIR-Y8 was detected. This band was not detected in WL-G. Strain specific band was detected from DNA fingerprint used in mixed DNA. The major band was common in WL-r5 and WL-G. In PCR analysis, the common band in both WL- $r 5$ and RIR-Y 8 was found. From these results, it was thought that the WL-r 5 genome was, for the most part, common with the recipient WL-G genome, except for a few genome from RIR-Y8 donor DNA. We thought that a few parts of donor DNA in WL- 55 were transferred through the irradiated sperm of donor RIR-Y8 male under successive selections for the brownish egg shell color from generation to generation.

(Jpn. Poult. Sci., 32, 151-160, 1995)

Key words : genetically transformed chicken, minisatellite DNA, microsatellite DNA, PCR, DNA fingerprint

\section{Introduction}

In our previous study, we succeeded in producing irradiated sperm transformed (IST) chickens by the use of double artificial inseminations of $\gamma$-ray irradiated donor sperm and unirradiated normal recipient sperm (Ү АмАмото and ТомітA, 1992). In that study, the resulting genetic factors responsible for the donor brownish egg shell color was $3.8 \%$ in the females of the first generation. It was suggested that the IST chickens produced by this technique integrated the fragmented donor DNA which contained the egg shell color gene(s) from the irradiated sperm. Then we tried to detect the DNA fragment from the irradiated donor sperm by DNA fingerprinting. It was revealed that $26.7 \%$ of embryos had foreign bands which were not possessed by the recipient

Received July 4, 1994 
parent (Yamamoto and Tomita, 1993).

In this study, attempts were made to detect the DNA from donor in the selected IST chicken line at minisatellite loci by DNA fingerprinting. DNA fingerprint analysis has been used for individual discrimination (JEFFreYs et al., $1985 \mathrm{a}, 1985 \mathrm{~b}, 1985 \mathrm{c}$ ), linkage estimation (JEFFreys et al., 1987a) and estimation of genetic relationship (KuHNLEIN et al., 1989). In addition, we compared the relationship between donor characteristic bands in IST chicken females and egg shell color variations. The genetic relationship between IST, donor and recipient chicken lines was analysed using DNA fingerprinting patterns. The typing of tandemly repeated hypervariable microsatellite loci was made by the polymerase chain reaction technique (PCR : SAIKI et al., 1985).

\section{Materials and Methods}

\section{Chickens}

In this study, the following adult chicken lines were used ; White Leghorn G (WLG, males 5, females 5) as recipient line, Rhode Island Red Y 8 (RIR-Y 8, males 6, females 6 ) as donor line, and White Leghorn $r 5$ (WL-r5, males 10 , females 10 ) as irradiated sperm transformed (IST) line. All chickens were maintained at the Poultry Research Institute, Aichi-ken Agricultural Research Center, Aichi, Japan.

\section{Blood samples}

Blood samples were taken from the wing vein with heparine sodium salt as anticoagulant. Samples were washed twice with saline and centrifuged.

\section{DNA extraction and digestion}

DNA was prepared from whole blood samples as described by Ciulia et al., (1988) and Maniatis et al., (1989). DNA samples thus extracted were digested overnight with 10 unit of HaeIII or HinfI (Nippon Gene)/ $\mu$ g under the conditions recommended by the suppliers. Before loading onto the gel, all DNA samples were extracted twice with phenol/chloroform $(1: 1)$, once with chloroform, precipitated with ethanol, and dissolved in distilled water.

\section{Electrophoresis and Southern blotting}

After restriction endonuclease digestion, the DNA was fractionated by electrophoresis in a $1.0 \%$ agarose gel of $40 \mathrm{~cm}$ long, in $1 \times$ TAE buffer $(40 \mathrm{mM}$ Tris-acetate, $1 \mathrm{mM}$ EDTA, pH 8.0) at a constant voltage $(5 \mathrm{~V} / \mathrm{cm})$. Electrophoresis was carried out at room temperature for 48 hours in nonrecirculating buffer tanks. To prevent $\mathrm{pH}$ change, the buffer was renewed every 12 hours. After electrophoresis, the gel was stained with ethidium bromide solution and photographed under ultraviolet (UV) light. DNA in gel was nicked with $500 \mathrm{~m} l$ of $250 \mathrm{mM} \mathrm{HCl}$ for $30 \mathrm{~min}$, denatured with $500 \mathrm{~m} l$ of $1.5 \mathrm{M}$ $\mathrm{NaCl}, 0.5 \mathrm{M} \mathrm{NaOH}$ for $30 \mathrm{~min}$, and neutralizd with $500 \mathrm{~m} l$ of $1.5 \mathrm{M} \mathrm{NaCl}, 0.5 \mathrm{M}$ Tris- $\mathrm{HCl}$ solution ( $\mathrm{pH}$ 7.5) for $30 \mathrm{~min}$. DNA was transferred from the gel onto a nylon hybridization membrane (Hybond-N+, Amersham) by capillary Southern blotting (SoutherN, $1975)$ in a $20 \times \mathrm{SSC}(1 \times \mathrm{SSC}: 0.15 \mathrm{M} \mathrm{NaCl}$ and $0.015 \mathrm{M}$ Trisodium citrate $)$ overnight. The DNA was fixed by soaking with $0.4 \mathrm{M} \mathrm{NaOH}$ for $2 \mathrm{~min}$. The membrane was rinsed with a $5 \times \mathrm{SSC}$ solution for one min. 


\section{Hybridization}

Membranes were hybridized with bacteriophage M13 mp18 RFI DNA (7249 bp, TAKARA) labelled by the nonradioisotopically enhanced chemiluminescence (ECL) method (Amersham) at $42^{\circ} \mathrm{C}$ overnight. The M 13 probe DNA has tandem repeats of 15 $b p$ consensus sequence (GAGGGTGGXGGXTCT) in the gene coding for the protein III region (VASSART et al., 1987 ; RYSKOv et al., 1988 ; GATEI et al., 1991). The ECL gene detection system kit (Amersham) was used according to manufacturer's protocol. Membrane washing was carried out by two steps. First washing was carried out once with $0.1 \%$ sodium dodecyl sulfate (SDS) and $0.5 \times \mathrm{SSC}$ at room temperature for $20 \mathrm{~min}$. The second washing was done twice with the $1 \times \mathrm{SSC}$ solution at room temperature for $5 \mathrm{~min}$. Membranes were exposed to the autoradiography film (Hyperfilm-ECL, Amersham) for 1 hour at room temperature.

$P C R$ analysis

Genomic DNA was diluted at $10 \mathrm{ng} / \mu \mathrm{l}$. Fifty $\mathrm{ng}$ of template DNA was amplificated by VNTR (variable number of tandem repeat) Fingerprinting system (Biotech International). This system was used for human individual typing based upon a hypervariable region at the $3^{\prime}$ end of the apolipoprotein B gene (Apo B, BEORWINKLE et al., 1989). Modified PCR method was used according to the manufacturer's protocol. The sequence of the $5^{\prime}$ oligonucleotide used to prime the PCR was $5^{\prime}$-ATGGAAACGGAGAAATTATG- $3^{\prime}$. The sequence of the $3^{\prime}$ PCR primer was $5^{\prime}$-CCTTCTCACTTGGCAAATAC- $3^{\prime}$. Initial incubation of denaturation was at $94^{\circ} \mathrm{C}$ for $5 \mathrm{~min}$ and $58^{\circ} \mathrm{C}$ for $6 \mathrm{~min}$, followed by 38 cycles of denaturation at $94^{\circ} \mathrm{C}$ for $1 \mathrm{~min}$, annealing and polymerization at $58^{\circ} \mathrm{C}$ for $6 \mathrm{~min}$. Final incubation was carried out at $94^{\circ} \mathrm{C}$ for $1 \mathrm{~min}, 58^{\circ} \mathrm{C}$ for 15 min and $25^{\circ} \mathrm{C}$ for $5 \mathrm{~min}$. The $10 \mu \mathrm{l}$ of PCR products were electrophoresed in a $3 \%$ agarose gel at $100 \mathrm{~V}$ constant voltage in $1 \times \mathrm{TAE}$ running buffer and detected by staining with ethidium bromide solution under UV light.

BS values

To assess the genetic similarity of DNA fingerprint bands between three chicken lines, the proportion of band sharing $(B S)$ value was calculated as :

$$
B S a b=2(N a b) /(N a+N b),
$$

where $B S a b=$ level of band sharing between lines a and b, Nab=number of bands shared by line a and b, $N a$ and $N b=$ total number of bands for line a and line b, respectively (Jefreeys and Morton, 1987b ; Wetton et al., 1987 ; Dunnington et al., 1990). Analysis of DNA fingerprints was carried out on DNA fragments larger than about 4 $k b$.

\section{Egg shell color values}

Photometric measurements of egg shell color at 180 days were carried out with a reflection photo difference meter (TC-1500MC, Tokyo Denshoku, brightness : L-value, red component : a-value and yellow component : b-value) at the blunt end of the egg. For the synthetic estimates of egg shell color, $Z$ values were calculated for each egg by a discriminate function formula using three color values (ҮАмамото and Томіта, 1992). 


\section{Results}

Genetic similarities among three lines using band sharing $(B S)$ value are shown in Table 1. Mixed DNAs of each line were used. The $B S$ value between WL- $r 5$ and WL$\mathrm{G}$ digested with $\mathrm{HaeIII}$ was calculated as 0.61 according to formula (1). The $B S$ value were 0.26 and 0.24 between WL-r 5 and RIR-Y8, WL-G and RIR-Y8, respectively. The $B S$ values digested with HinfI was 0.48 between WL- $r 5$ and WL-G, 0.15 between WL$r 5$ and RIR-Y 8 and 0.19 between $\mathrm{WL}-\mathrm{G}$ and RIR-Y8, respectively.

The band of WL- $r 5$ common to RIR-Y 8 was found in DNA fingerprint of mixed DNA digested with HinfI (Fig. 1-A). This common band appeared at about $7.0 \mathrm{~kb}$ (indicated by closed triangle). Moreover, this common band was found in six (A), (B), (C), (G), (I) and (J) of tenWL- $r 5$ females (Fig. 1-B) and two (852 and 849) of ten WL-r5 males (Fig. 1-C) used Hinfl digested individual DNA fingerprint. The data were shown for only two females ( $\mathrm{G}$ and $\mathrm{I}$ ) in Fig. 1-B.

Fig. 2 shows line characteristic bands pattern using mixed DNA digested with HinfI enzyme. WL- $r 5$ and $\mathrm{WL}-\mathrm{G}$ lines possesed a common band (the arrow indicate, about $21.0 \mathrm{~kb}$ ) in a major band. The minor bands appeared to be line characteristic and were expressed strongly in male. RIR-Y8 line showed different banding pattern as compared with WL-r5 and WL-G lines.

The results of PCR analysis are shown in Fig. 3. The line characteristic band (the arrow indicate, about $2100 \mathrm{bp}$ ) was detected by electrophoresis of amplificated PCR products by the primer of the human apolipoprotein B (Apo B) gene 3 ' hypervariable region. All WL-r5 males and females used in this study had this specific band. In the RIR-Y8 line, some chickens were positive in having this band and others were not. WL-G chickens did not have this band.

Photometric values of egg shell color were measured for the three components (Lvalue, brightness ; a-value, red component, and ; b-value, yellow component) in ten females of WL- $r 5$ line. For example, the dark or brown shell color like Rhode Island Red eggs gave a low L-value, high a-value and high b-value compared with those of the pure white shell color like White Leghorn eggs. As shown in Table 2, the egg shell color values if WL-r5 (A) to (J) females varied gradually. The (A) female laid the most brownish dark color shell eggs (L-value, 75.0 ; a-value, 3.7, and ; b-value, 18.1) in WL$r 5$ females at 180 days, and the (J) female laid the most whitish light color shell eggs (L-value, 82.4 ; a-value, 0.5 , and ; b-value, 11.7). The means of three values for WL-r5

Table 1. Comparison of genetic similarity between WL- $r 5$, WL-G and RIRY8 lines of chickens using band sharing $(B S)$ values of DNA fingerprinting deected by mixed DNA and probe M13 phage DNA

\begin{tabular}{|c|c|c|c|c|c|c|c|c|c|}
\hline \multicolumn{2}{|c|}{ Line } & \multicolumn{4}{|c|}{ Hae III } & \multicolumn{4}{|c|}{ Hin $\mathrm{fI}$} \\
\hline$a$ & $b$ & $\mathrm{Na}$ & $\mathrm{Nb}$ & $N a b$ & $B S$ & $\mathrm{Na}$ & $\mathrm{Nb}$ & $N a b$ & $B S$ \\
\hline WL-r 5 & WL-G & 99 & 103 & 62 & 0.61 & 87 & 95 & 44 & 0.48 \\
\hline WL-r 5 & RIR-Y8 & 99 & 99 & 26 & 0.26 & 87 & 98 & 14 & 0.15 \\
\hline $\mathrm{WL}-\mathrm{G}$ & RIR-Y8 & 103 & 99 & 24 & 0.24 & 95 & 98 & 18 & 0.19 \\
\hline
\end{tabular}



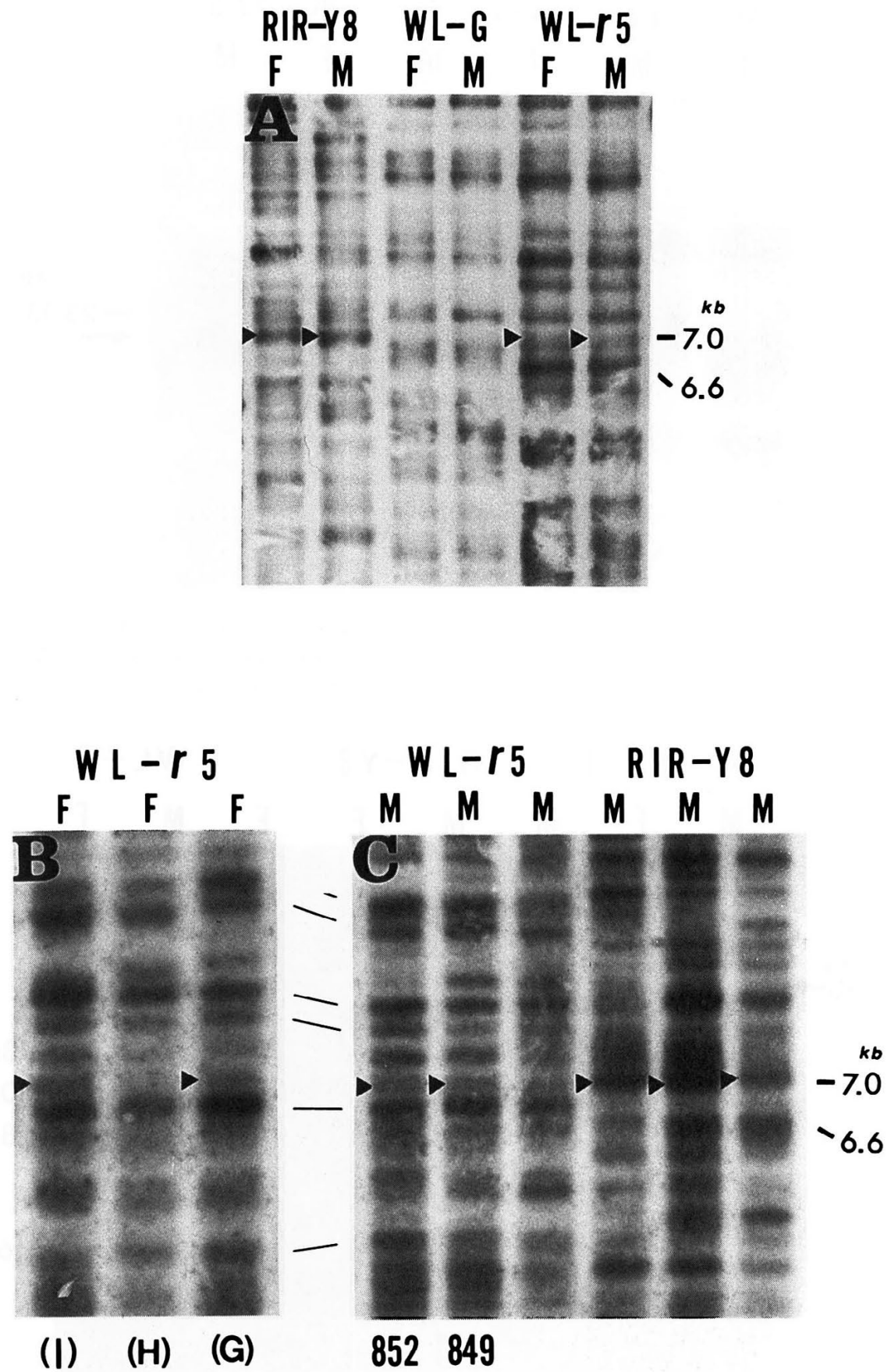

Fig. 1. Comparison of the WL-r 5, WL-G and RIR-Y8 DNA fingerprints. A: The common band found in WL-r 5 and RIR-Y8 lines. Mixed DNA was used. B : The common band found in WL- 5 females. Individuals DNA was used. C : The common band found in WL- $r 5$ and RIR-Y 8 males. Each DNA was digested with Hinfl and hybridized with M 13. F : female, M : male, : common band. 


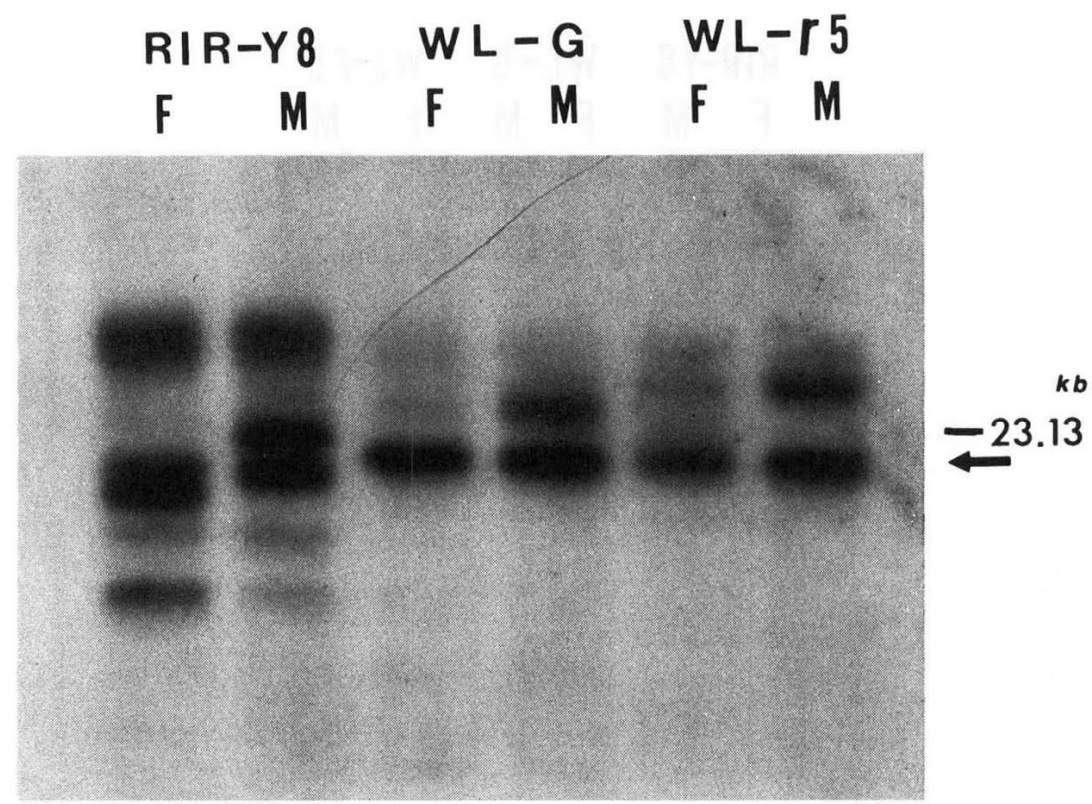

Fig. 2. Line characteristic band pattern of RIR-Y 8, WL-G and WL- 5 lines. Mixed DNA was used after digestion with Hinfl and hybridized with M 13. $\Rightarrow$ : characteristic band in WL- $r 5$ and WL-G. F : female, M : male.

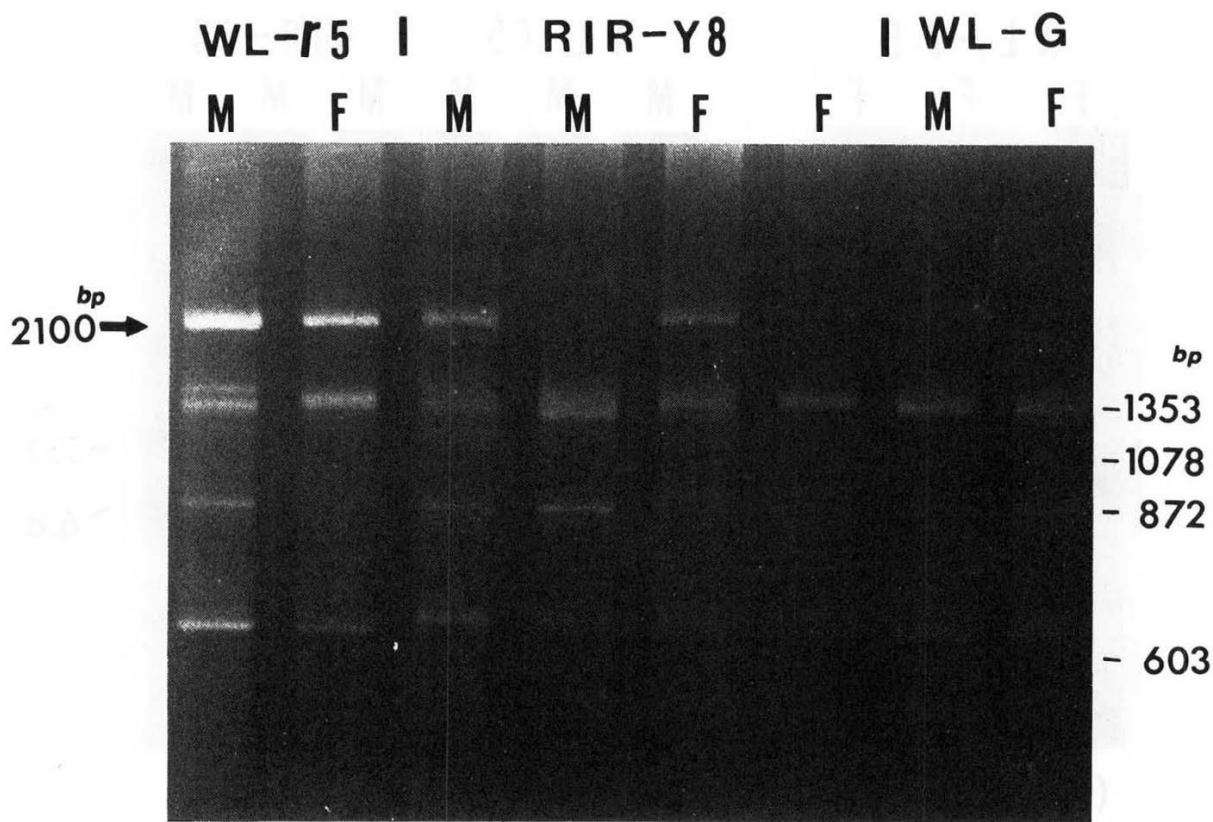

Fig. 3. PCR analysis of microsattelite DNA of the WL- $r 5, \mathrm{WL}-\mathrm{G}$ and RIR-Y 8 lines. The primer for detecting human apolipoprotein $\mathrm{B}$ gene $3^{\prime}$ hypervariable region was used. $\Rightarrow$ : characteristic band in WL-r 5 and RIR-Y 8. M : male, $\mathrm{F}$ : female.

line (L-value, 78.1 \pm 2.3 ; a-value, $2.0 \pm 0.9$, and ; $b$-value, $15.1 \pm 1.9$ ) were shown to be intermediate between WL-G and RIR-Y8 lines. We attempted to compare the $Z$ value using three color values and DNA fingerprint bands, but there was no relationship 
Table 2. Photometric and $Z$ values of egg shell color of WL $-r 5$ females at 180 days and the means of three color values of WL- $r 5$, WL-G and RIR-Y 8 lines with the number of genetically transformed bands detected in DNA fingerprint digested with Hin fI

\begin{tabular}{ccccccc}
\hline $\begin{array}{c}\text { WL- } r 5 \\
\text { females }\end{array}$ & No. of eggs & $\begin{array}{c}\text { L-value } \\
\text { (brightness) }\end{array}$ & $\begin{array}{c}\text { a-value (red } \\
\text { component) }\end{array}$ & $\begin{array}{c}\text { b-value } \\
\text { (yellow } \\
\text { component) }\end{array}$ & Z value & $\begin{array}{c}\text { No. of } \\
\text { transgenic } \\
\text { band }^{*}\end{array}$ \\
\hline 446 (A) & 1 & 75.0 & 3.7 & 18.1 & -0.64 & 1 \\
445 (B) & 1 & 76.0 & 2.8 & 17.4 & -0.42 & 1 \\
439 (C) & 1 & 74.4 & 3.2 & 17.4 & -0.39 & 1 \\
436 (D) & 1 & 77.6 & 2.0 & 16.9 & -0.28 & 0 \\
437 (E) & 1 & 76.2 & 3.0 & 15.3 & -0.11 & 0 \\
438 (F) & 1 & 78.1 & 1.8 & 14.2 & 0.05 & 0 \\
443 (G) & 1 & 79.8 & 1.2 & 14.7 & 0.17 & 1 \\
442 (H) & 1 & 80.1 & 1.0 & 13.4 & 0.36 & 0 \\
444 ( I ) & 1 & 81.7 & 1.1 & 11.8 & 0.54 & 1 \\
447 (J) & 1 & 82.4 & 0.5 & 11.7 & 0.63 & 1 \\
\hline WL-r5 & 10 & $78.1 \pm 2.3^{*}$ & $2.0 \pm 0.9$ & $15.1 \pm 1.9$ & - & - \\
WL-G & 549 & $87.9 \pm 1.0$ & $-1.6 \pm 0.3$ & $5.2 \pm 1.8$ & - & - \\
RIR-Y8 & 147 & $61.5 \pm 3.3$ & $5.3 \pm 0.8$ & $18.9 \pm 1.1$ & - & - \\
\hline
\end{tabular}

* : Mean $\pm \mathrm{SD}$

\# : DNA band from RIR-Y8.

found between the orders of DNA fingerprinting and $Z$ value.

\section{Discussion}

DNA fingerprint method was able to detect many loci at the same time, and was a very powerful tool for analysis of the genetic profile of population (JEFFREYs et al., 1985 c ; JEFFrEYs and MORTON, 1987 b). DNA fingerprinting results showed higher individual specificity (GEORGES et al., 1988). Our probe DNA used was bacteriophage M13 whole DNA, which was highly informative and a powerful universal probe in almost all species. But this probe DNA could not detect the relationship between DNA fingerprint band and a quantitative trait factor like egg shell color.

Mixing DNA from individuals representing a line has been used for line identification (Dunnington et al., 1990). The mixed DNA can be used efficiently for linkage analysis between DNA fingerprint loci and quantitative trait loci (QTL) (PLOTSKY et al., 1990). All WL-r5 females used in these studies laid brownish tinted color eggs, but we could not recognize the relationship between DNA fingerprint bands and egg shell color. Other probes which contained repetitive minisatellite sequences might work effectively for the purpose.

The $B S$ values between WL-r5 and WL-G DNA digested with HaeIII and HinfI were 0.61 and 0.48 , respectively. These values may reflect that $\mathrm{WL}-r 5$ shares with a half or more similar genomic DNA constitution with that of WL-G. Moreover, this result may indicate that $\mathrm{WL}-r 5$ chickens are not hybrid of $\mathrm{WL}-\mathrm{G}$ and RIR-Y8, because the $B S$ values between $\mathrm{W}-r 5$ and RIR-Y 8 calculated were very low 0.26 in HeaIII and 0.15 in HinfI). Similar value between WL-G and RIR-Y8 (0.24 in HaeIII and 0.19 in 
HinfI) was obtained.

The common band was detected in mixed DNA digested with HinfI from WL-r5 and RIR-Y8. This common band was not detected in the WL-G DNA fingerprint. It was suggested that this common band was derived from the donor RIR-Y8 sperm DNA from the first IST chicken generation, although we could not establish that this band is relating to the egg shell color gene(s).

The primer of PCR reaction used in this study was used for the analysis of human individuality based on apolipoprotein B (Apo B) 3' hypervariable region (BOERWINKLE et al., 1989). The amplification of human genomic DNA with this human specific primer could produce Apo B 3' region in large quantities without nonspecific bands. The reaction conditions used in our study were the same as those used for human DNA analysis. This primer amplificated the chicken genome DNA and some bands were detected. We thought that these bands obtained were not related to Apo B 3' hypervariable region, but might reflect some unknown microsatellitet repetitive sequences.

The common bands between WL- $r 5$ and RIR-Y8 were detected in DNA fingerprint using mixed DNA digested with HinfI and in PCR method. From these results, it was thought that WL-r 5 chickens had, for the most part, the same genome as the WL-G genome, and had a few part of the RIR-Y8 genome component(s). This RIR-Y8 genome component(s) could be transferred from the genetically transformed chicken generations through the irradiated donor sperm.

If the genetically transformed chicken males which have donor specific DNA band related to the brown egg shell color were crossed to the females which lay brownish shell color eggs, the next generation females might lay brown color eggs more than mother females do. The egg shell color would be determined by a number of genes (McDonald 1959, Hunton 1962). Hurst (1905), Punnett and Bailey (1920), Benjamin (1920) and FARNSWORTH and NORDSKOG (1955) indicated that the inheritance of egg shell pigmentation depended on a large number of genes, each contributing a small amount to the trait. Gowe et al. (1965) suggested that some major genes causing the segregation of shell color seen in brown egg flocks probably had dominance effects based on the higher variance associated with dams as compared with sires. WEI et al. (1992) gives rise to a hypothesis of major genes contributing to the trait of tinted egg shell colors, and have confirmed that other alleles at the major loci might control brown egg shell colors.

We thought that all egg shell color genes were not transmitted to the individuals. In our previous study the transferred egg shell color genes from irradiated sperm were stable for at least five successive generations (Ү амамото and Томіта 1992). Further studies are necessary to confirm the expression of transferred genes other than the egg shell color genes.

\section{Acknowledgement}

The authors would like to thank staffs of Poultry Research Institute, Aichi-ken Agricultural Research Center for their help in conducting this study. 


\section{References}

BenJamin, E.W. (1920) A study of selections for the size, shape, and color of hen's eggs. New York Agricultural Experiment Station Memoir, 31 : 195-312.

Boerwinkle, E., W. Xiong, E. Fourest and L. Chan (1989) Rapid typing of tandemly repeated hypervariable loci by the polymerase chain reaction: Application to the apolipoprotein B 3 ' hypervariable region. Proceedings of the National Academy of Science. USA, $86: 212-216$.

Ciulia, T.A., R.M. Skalar and S.L. Hauser (1988) A simple method for DNA purification from peripheral blood. Analytical Biochemistry, $174: 485-488$.

Dunnington, E.A., O. Gal, Y. Plotsky, A. Haberfeld, T. Kirk, A. Goldberg, U. Lavi, A. Cahaner, P. Siegel and J. HiLleL (1990) DNA fingerprints of chickens selected for high and low body weight for 31 generations. Animal Genetics, $21: 247-257$.

FARNSWORTH, G.M. and A.W. NoRDSKOG (1955) Breeding for egg quality 3. Genetic differences in shell characteristics and other egg quality factors. Poultry Science, 34 : 16-26.

Gatei, M.H., P.M. Chen, R.C.W. Daniel and M.F. Lavin (1991) DNA fingerprints of sheep using an M 13 probe. Animal Genetics, $22: 285-289$.

Georges, M., A-S. Lequarre, M. Castelli, R. Hanset and G. Vassart (1988) DNA fingerprinting in domestic animals using four different minisatellite probes. Cytogenetics and Cell Genetics, $47: 127-131$.

Gowe, R.S., H.W. BudDE and P.J. McGanN (1965) On measuring egg shell color in poultry breeding and selection programs. Poultry Science, $44: 264-270$.

Hunton, P. (1962) Genetics of egg shell color in light Sussex flock. British Poultry Science, 3 : 189-193.

HURST, C.C. (1905) Experiments with poultry. Reproduction and Evolution Community Research Society. II. 131-154.

JefFreys, A.J., V. WiLson and S.L. Thein (1985 a) Hypervariable 'mini satellite' region in human DNA. Nature, $314: 67-73$.

JEFFREYS, A.J., V. WILSON and S.L. TheIN (1985 b) Individual-specific 'fingerprints' of human DNA. Nature, $316: 76-79$.

Jeffreys, A.J., J.F.Y. Brookfield and R. Semeonoff (1985c) Positive identification of an immigration test-case using human DNA fingerprints. Nature. 317 : 818-819.

Jefrreys, A.J., V. Wilson, R. Kelly, B.A. TAYLOR and G. Bulfield (1987a) Mouse DNA 'fingerprints' : analysis of chromosome localization and germ-line stability of hypervariable loci in recombinant inbred strains. Nucleic Acids Research. $15: 2823-2836$.

JefFreYs, A.J. and D.B. MorTon (1987 b) DNA fingerprints of dogs and cats. Animal Genetics, 18 : $1-15$.

Kuhnlein, U., Y. Dawe, D. Zadworny and J.S. Gavora (1989) DNA fingerprinting : a tool for determining genetic distances between strains of poultry. Theoretical and Applied Genetics. $77: 669-672$.

Maniatis, T., E.F. Fritsch and J. SAmbrook (1989) Molecular Cloning: A laboratory manual, Second edition, Cold Spring Harber Lab., N.Y.

MCDonald, M.W. (1959) Progeny testing for dominant white in meat type chickens. Poultry Notes, Department of Agriculture, New South Wales, Australia, October : 1-5.

Plotsky, Y., A. Cahaner, A. Harberfeld, U. Lavi and J. Hillel (1990) Analysis of genetic association between DNA fingerprint bands and quantitative traits using DNA mixes. Proc. 4th World Congr. Genet. Appl. Livestock Prod., Edinburgh, Vol. XIII pp. 133-136.

PunnetT, R.C. and P.G. BAILEY (1920) Genetic studies in poultry : II. Inheritance of egg-colour and broodiness. Journal of Genetics, $10: 277-292$.

Ryskov, A.P., A.G. Jincharadze, M.I. Prosnyak, P.L. Ivanov and S.A. Limborska (1988) M 13 phage DNA as a universal marker for DNA fingerprints of animals, plants and microorganisms. FEBS, 233 : 388-392.

Saiki, R.K., S. Scharf, F.A. Faloona, K.B. Mullis, G.T. Horn, H.A. Erlich and N. Arnheim (1985) Enzymatic amplification of $B$-globin sequences and restriction site analysis for diagnosis of sickle cell anemia. Science, 230 : 1350-1354. 
Southern, C.M. (1975) Detection of specific sequences among DNA fragments separated by gel electrophoresis. Journal of Molecular Biology. 98 : 503-517.

Vassart, G., M. Georges, R. Monsieur, H. Brocas, A.S. Lequaree and D. Christophe (1987) A sequence in M13 phage detects hypervariable minisatellite in human and animal DNA. Science, 235 : 683-684.

WeI, R., J.J. Bitgood and M.R. Dentine (1992) Inheritance of tinted eggshell colors in white-shell stocks. Poultry Science, $71: 406-418$.

Wetton, J.H., R.E. Carter, D.T. Parkin, and D. Walters (1987) Demographic study of a wild house sparrow population by DNA fingerprinting. Nature, 327 : 147-149.

Yамамото, N. and T. Tомiт A (1992) Genetic transformation of egg shell color in chicken by the use of irradiated sperm. Japanese Poultry Science, 29 (4) : 213-220.

Yамамото, N. and T. Tоміта (1993) Detection of $\gamma$-ray irradiated donor sperm DNA in the transgenic chicken embryo by DNA fingerprint analysis. Japanese Poultry Science, 30 (2) : $114-122$.

\title{
遺伝的形質転換二ワトリのミニおよび マイクロサテライト DNA による解析
}

\author{
山本直幸 ${ }^{1)} \cdot$ 木野勝敏 $^{2)} \cdot$ 加藤秀樹 $^{1)} \cdot$ 山縣高宏 $^{3)} \cdot$ 富田 武 ${ }^{3)}$ \\ 1)（財）実験動物中央研究所, 川崎市宮前区野川1430216 \\ 2) 愛知県農業総合試験場, 愛知郡長久手町岩作字三ヶ峯 480-11 \\ 3) 名古屋大学農学部, 名古屋市千種区不老町 464-01
}

ガンマー線を照射したドナー精子と非照射レシピエン 卜正常精子により作出した遺伝的形質転換ニワトリの第 5 世代における DNA を解析した。ミニサテライトDNA の分析にはフィンガープリント法を, またマイクロサテ ライトDNAの分析には遺伝子増幅（PCR）法をそれ ぞれ用いた。供試鶏は遺伝的形質転換系 WL-r5, レシピ エント系 WL-G，およびドナー系 RIR-Y8 の各雄雌で ある。本奏験で用いた条件下では卵款色と個体毎の DNA フィンガープリントバンドとの間に相関関係を認 めることはできなかった。各系統毎に雄雌別の DNAを 混令し，系統の特徴を反映したDNAフィンガープリン ト像を作成した。この結果を計算式に当てはめ，遺伝的 相似性（BS 值）を求めた。WL-r 5 と WL-G との比較に おけるBS 值は，0.61 (HaeIII) および 0.48 (HinfI) で あった。この $B S$ 值より推足すると, WL- $\boldsymbol{r}$ は WL-Gと の間に約半分あるいはそれ以上の相似的 DNA を持つと いうことが小唆される。WL-r5とRIR-Y 8，または WL-G と RIR-Y8 の比較で得られた $B S$ 值は低く, 相似 州は非常に少ないと考えられる。雄雌別の混合 DNA に より作出した DNA フィンガープリントから，WL-r5 とRIR-Y8 に共通で, かつWL-Gには存在しないバン ドが, HinfI で消化した DNAにおいて 1 本確認された。
また, WL- $r 5$ と RIR-Y 8 の個体毎の DNA フィンガー プリントでは, このバンドをもつものが雄で 2 個体, 雌 で 6 個体に確認された。混合 DNA の解析では, 系統を 特徴的に示すようなバンドが見られた。PCR 法による 解析では, WL- $r 5$ と RIR-Y8 に共通で, かつ WL-Gに 存在しないバンドが確認された。WL-r5 雌が 180 日齢 に産んだ卵の卵款色の 3 成分（L值：明るさ， a 值 : 赤 色, $\mathrm{b}$ 值 : 黄色) を測定したところ, 着色の程度が高いあ のから低いものまで連続的な結果が得られた。3成分の 平均值は WL-G と RIR-Y8のほぼ中間の值を示した。 以上の結果を総合的に判断すると，WL-r 5 のゲノムは WL-G と多くの相似性をむち，わずかではあるが RIRY8の DNA とも類似する点をもつということが推察さ れた。RIR-Y8 との相似性は，遺伝的形質転換第 1 世代 （WL-r1）において獲得したドナー精子由来の DNA が WL- $r 5$ まで安定的に伝達されてきた結果であろうと考 えられた。

（家禽会誌, $32: 151-160,1995)$

キーワード：遺伝的形質転換ニワトリ，ミニサテライト DNA，マイクロサテライト DNA, PCR, DNA フィンガープリント 